\title{
Strategy of Management of City Development with Using «Green» Technologies (Kazan City, Russia)
}

\author{
Mingazova N.M.
}

Kazan Federal University, Kazan, 420008, Russia

Email:nmingas@mail.ru

Nikitin A.V.

Kazan Federal University, Kazan, 420008, Russia

Yupina G.A.

Kazan Federal University, Kazan, 420008, Russia

Derevenskaya O.Yu.

Kazan Federal University, Kazan, 420008, Russia

\section{Doi:10.5901/mjss.2014.v5n18p341}

\begin{abstract}
Strategic management of the city should take into account questions related to improving the environment and quality of life. For environmental improvements in Kazan city (Russia) used elements of strategic and tactical management with the introduction of "green» technologies. As instrument developed and successfully implemented municipal program "Green record." This program was developed municipalities in collaboration with scientists of Kazan Federal University. Scientific and theoretical foundations of the program are the conception of «ecological carcass (or framework) ». The program is based on the results of studies on the inventory of city green planting. The realization of program has increased the gardening degree from 17 to $23 \%$. Subsequent steps of the program «Green record» will increase the gardening degree and form the elements of structure of the «ecological carcass».
\end{abstract}

Keywords: strategic management, city development, "green" technologies, municipal program, green record, ecological carcass.

\section{Introduction}

Specificity of the strategic city management is to manage public relations, transparency of public inspection. Management of the city cannot be aggressive towards the environment and health of the population [3]. Strategic management is based on the concept of the enterprise as a stable and an isolated system, the operational management - on maintaining high mobility and handling processes and objects. Tactical type occupies an intermediate position [1].

Urban economy requires solving many different issues - social, economic, public, transport, environment and others. Management strategy should include environmental issues. In cities with environmental degradation arise ecological and social conflicts. A stakeholder to resolve them is not only the population, but also heads of municipalities and utilities. Improving the environment can be solved through a series of events: changes in territorial planning, improved wastewater treatment and air emissions, increasing the degree of gardening, landscaping, preservation of natural areas, and more. An example of the development of management strategies in urban areas is the introduction of municipal «green» technologies.

The aim of the research is to assessment of the opportunities in the city the «green» technologies through municipal authorities, including technology of «ecological carcass». The objectives included assessment of the gardening degree on the basis of the inventory of green planting, the dynamics of this index data, the development of the structural elements of the ecological carcass. 


\section{Method}

We used the inventory of green space, implemented in Kazan in 2007-2014 years. Work carried out by the municipal contract with administration of the city of Kazan.

\section{Results}

\subsection{The ecological carcass structure and its types}

Ecological carcass in general terms is a system of continuous green areas and water areas aimed at increasing the gardening degree and the preservation of natural areas. A consequence of its creation is to improve air quality, increase recreational areas and other [4]. Due to the nature of urban development are two main types of ecological carcass «radial» and «rod». «Radial» type is characteristic for cities with radial location from the center. In the city center formed the «core» (a large natural object - a park, forest or lake) and «wedges» (natural areas connected with the «core»). «Wedges» can be interconnected «green corridors» (continuous green areas). «Wedges», in turn, be connected with large natural objects outside the city (there is formed a «green ring» or «water arch»). Many Russian and European cities have a radial structure landscaping. For them to be successful implementation of the «radial» frame structure, aimed at creating the missing elements («core», «wedge», «green corridors»). Cities, developing along the riverbanks, characterized by linear or strip types of landscaping. For them to be successful implementation of the «rod» types of ecological carcass, aimed at greening the coast [4].

\subsection{Structure of ecological carcass of the Kazan city}

Kazan city - the capital of the Tatarstan Republic (1.1 million people). The city is located in the east of European part of Russia. History of development (over 1,000 years) defined role for the city transit point between the western and eastern regions of the country, European and Asian cultures. Intensive technological impact and geographical location determines complicated ecological situation [6].

The ecological carcass for the Kazan city refer to the territorial planning project - «General plan of the Kazan city» [2]. But it was not based on actual data on gardening, so was not implemented. Thus, the type of strategic management was not supported by tactical measures.

The authors work revealed that the city can be developed ecological carcass structure of mixed type - «radial rod» [4]. But creation of it requires the administrative decisions of municipalities through municipal programs. Scientific and theoretical basis of such programs may be the conception of ecological carcass, based on the results of inventories of natural sites of the city and the gardening degree.

\subsection{Analysis of the state of green plantings in Kazan}

The most important indicator of the green fund is urban green area. Standard indicator area landscaping for cities in Russia is $40 \%$ of the total area and $55 \%$ for industrial cities. The green area of Kazan city in 2002 was only $22.65 \%$ (Table 1). On January 1, 2003, the total green area of the city is 9631 hectares, of which public spaces 1562 hectares (gardens, parks, squares, green zones). During 2003, it was planted about 33,000 trees and 66,000 shrubs. Total number of green space was 225,584 trees and 690,653 shrubs [5].

Table 1. Condition of green fund of Kazan in 2002

\begin{tabular}{|c|c|c|c|c|}
\hline Name of city & The total area, ha & The total built-up area, ha & The total area of green space, ha & Landscaping, $\%$ \\
\hline Kazan & 42520 & 13000 & 9631 & 22,65 \\
\hline
\end{tabular}

Degree of gardening by municipal districts vary greatly. The maximum number accounted for of Kirovskiy municipal region (over 30\%), which is a large forest park «Lebyazhe».

According to the inventory of green space, conducted authors of this article under contract with the municipal authorities, on January 1, 2008 to the public plantings 190 objects related. Among them 16 parks, 5 - public gardens, 109 - squares, 59 - green areas and urban forest «Lebyazhe». They grow 274895 trees belonging to the 71 species. For the period 2002-2007 the number of trees to quantify increased by $20 \%$. 
In 2008-2011 due to the massive construction of transport routes, shopping centers, housing and sports objects for international competitions, green area of the city was reduced to $17 \%$.

\subsection{Municipal program as a management instrument}

Since 2012, the city is implementing the measures of the municipal program "Green record." Purpose of program - a mass planting of the city and the places affected by the construction, with planting 50,000 trees per year. As a scientific and theoretical foundations of the program for the municipal bodies of the authors proposed the conception of ecological carcass. Cooperation on this issue has led to the fact that for the program a special environmental public council was organized. It included representatives of urban structures, control authorities, academics, and representatives of the population and public organizations. The board meetings held in 2012-2013 to discuss the conception of ecological carcass, discussed the measures necessary for the establishment of an ecological carcass and realization of the program (Table 2).

Table 2. The matrix analysis of interaction in the implementation of program "Green record"

\begin{tabular}{|l|c|c|c|c|c|}
\hline Structure and activities & Municipalities & $\begin{array}{c}\text { Controlling } \\
\text { authorities }\end{array}$ & Utility and industrial structures & Scientists & Community organizations \\
\hline Solution about Program & + & & & & \\
\hline Control & & + & & & + \\
\hline Realization & + & & + & & + \\
\hline Proposals & + & & & + & + \\
\hline
\end{tabular}

In implementing the program «Green record» first greened areas along highways and construction sites. Currently, in accordance with the conception of ecological carcass carried landscaping along the coast for creation a «core» of carcass and its connection to the «wedges». Work has begun on the conservation of valuable natural areas of the city as protected zones. They will enter the frame elements such as «wedges», «green corridors» and part of the «green ring». Total during the program (2012-2013) planted more than 100,000 large trees in the age of 4-5 years. It is possible to increase the gardening degree to about $23 \%$.

\section{Conclusion}

For environmental improvements in Kazan city used elements of strategic and tactical management of urban development with the introduction of «green» technologies. As a tool developed and successfully implemented municipal program «Green record». With it introduced the conception of the ecological carcass of the city and its structure is created. The program has increased the gardening degree from 17 to $23 \%$. Subsequent steps of the program «Green record» will increase the degree of landscaping and to form elements of the structure of Kazan city ecological carcass.

\section{References}

Business strategy: an analytical handbook / Edited by G.B. Kleiner. - Moscow, publishing «CONCECO», 1998. - 170 p.

Ecology of Kazan / Edited N.M. Mingazova etc. - Kazan, publishing «FEN», 2005. - 575 p.

Kafidov, V.V. Research management systems. - Ekaterinburg, 2005. - 150 p.

Nikitin A.V., Mingazova N.M., Yupina G.A. Problems of formation of ecological-natural carcass of urban areas (for example, Kazan) // The News of the Kazan State University of Architecture and Construction, 2010, № 2 (14 ), p. 88-96.

The Program «Environmental Health Kazan on 2004-2008» / Edited N.M. Mingazova etc. - Kazan, 1984. - 75 p.

The development strategy of the city of Kazan to 2015 / Edited M.V. Panasiuc etc. - Kazan, 2003. - 65 p. 
